\title{
Genotoxic Effects of Spirotetramat on Allium Cepa $\mathrm{L}$.
}

\author{
Mehmet Huseyin Gultekin \\ Canakkale Onsekiz Mart University, School of Graduate Studies, \\ Subdivision of Biology, 17020, Canakkale, Turkey \\ E-mail: mehmethuseyingultekin@gmail.com \\ Cuneyt Aki \\ Canakkale Onsekiz Mart University, Faculty of Science and Arts, \\ Department of Biology, Subdivision of Molecular Biology, 17020, Canakkale, Turkey \\ E-mail: cuneytaki@comu.edu.tr
}

\begin{abstract}
In this research the genotoxic effects of spirotetramat have been determined by the meaning of mitotic index (MI) and chromosomal abnormality in Allium cepa L. root tip meristematic cells. For this purpose the Allium test was carried out exposing roots to spirotetramat for 24 and 48 hours at the concentrations of $1 \mathrm{~mL} / \mathrm{L}, 2 \mathrm{~mL} / \mathrm{L}, 4 \mathrm{~mL} / \mathrm{L}$. After the spirotetramat applications, root tips have been harvested and standard mitotic test procedures have been realized. The mitotic index was calculated as the number of dividing cells per number of 1000-1500 observed cells and the chromosomal aberrations also were scored for each group. Our results have showed that the mitotic index significantly decreased with the increase of doses and exposure times when compare to their controls.

According to our results, MI value has been decreased as $56 \%$ and $65 \%$ in $4 \mathrm{~mL} / \mathrm{L}$ spirotetramat application after 24 and 48 hours respectively. As a result of our research, it was understood that the chromosomal aberration frequency increased in all application groups when we compare with the control group. According to chromosomal aberration frequency results, when we compare with control group chromosome aberration frequency increased approximately seven fold in $4 \mathrm{~mL} / \mathrm{L}$ spirotetramat applications after 24 and 48 hours respectively. Our results showed that spirotetramat induced significant increases of chromosomal aberrations such as table and pole shifting, chromosomal bridge. In addition that mitotic index (MI) decreased significantly with increasing of spirotetramat doses and the exposure time as compared to their controls.
\end{abstract}

Keywords: Allium cepa, spirotetramat, genotoxicity, mitotic index.

DOI: $10.7176 / \mathrm{JSTR} / 7-06-03$

\section{Introduction}

The most important problem of our century is the increase in the need for food products brought by the population growth, and the existing agricultural areas are inadequate (Kılıç, 2013). With the growing population, efficient farmland is destroyed in the same proportion in the future as it progresses parallel to urbanization, or even faster. Therefore, many biological and modern techniques are used to obtain max yield from the fields of crop (Durmuşoğlu et al., 2010). In order to achieve maximum efficiency, agricultural pests must be eliminated. For this purpose, pesticides are frequently used (Dağ et al., 2007).

There are hundreds of pathogen which related with common plant diseases. All of the plant diseases cause crop losses. Herbicides are used against weeds, fungicides against fungi, rodenticides against rodents and insecticides against insects. Insects with the potential to cause damage to their full yield capacity are represented by hundreds of thousands of species.

Against these insect species, which have a wide range, 5 different insecticide groups are produced: organochlorines, organophosphates, carbamates, pyrethroids and neonicotinoids (Yadav and Devi, 2017). The insecticides used for years have been inadequate, were insufficient, a new synthetic active ingredient, spirotetramat from the group of cyclic ketoenols, was introduced to the market as 'Movento 100 SC' (Guest et al., 2020).

Recommended doses of spirotetramat use in cultivation areas apple (Malus sp., $50 \mathrm{ml} / 100 \mathrm{~L}$ water),

25 | P a g e

www.iiste.org 
pear (Pyrus sp., $100 \mathrm{ml} / 100 \mathrm{~L}$ water), watermelon (Citrullus sp., $75 \mathrm{ml} / \mathrm{da}$ ), pepper (Capsicum sp., 100 $\mathrm{ml} / 100 \mathrm{~L}$ water), eggplant (Solanum sp., $100 \mathrm{ml} / 100 \mathrm{~L}$ water), Pistachio (Pistacia sp., $100 \mathrm{ml} / 100 \mathrm{~L}$ water), tomato (Solanum sp., $75 \mathrm{ml} / \mathrm{da}$ ), onion (Allium sp. , $100 \mathrm{ml} / \mathrm{da}$ ). Spirotetramat; LD50 > 2000 $\mathrm{mg} / \mathrm{kg} \mathrm{kg} \mathrm{bw}$, orally taken when inhalation by LC50 $>4183 \mathrm{mg} / \mathrm{m} 3$ and LD50 $>$ skin contact case in $2000 \mathrm{mg} / \mathrm{kg}$ bw (http://www.fao.org).

The Allium test is an economical, fast reliable test that has been used for many years. A. cepa is preferred because the chromosome number is low and the chromosomes are large and observable (Kuras et al., 2006; Rank, 2003). This test, where the mitotic index can be observed with ease, the mutagenic effects of physical and chemical substances can be easily observed. In addition, since it is known that the results of this test and mammalian test systems overlap with each other, it allows preliminary studies to be carried out (Teixeira, 2003; Vicenni, 2001; El-Shabbaby et al., 2003).

In the phase studies conducted prior to the release of spirotetramat, dose tests were conducted on the rats and mice and toxicological effects were investigated. According to these studies, it was observed that spirotetramat taken orally as $2 \mathrm{mg} / \mathrm{kg}$ did not show a toxic effect even if it was administered chronically for 14 days. It has been stated that the product, which is metabolized in the liver of rats, does not pose a hepatological hazard. (Australian Pesticides and Veterinary Medicines Authority, 2009). In another research, potential genotoxic effect of fipronil insecticide have been analyzed by studying mitotic index and chromosomal abnormalities in A. cepa root tips. The roots were treated with 1, 2.5, 5 and $10 \mathrm{ppm}$ of fipronil insecticide within 6,12 and 24 hours (Karaismailoglu, 2017).

In another research, toxic effects of methiocarb insecticide were investigated with using bulbs of Allium cepa. Cytogenetic effects were analyzed with micronucleus (MN), chromosomal damage and mitotic index. A. cepa control group were treated with tap water, application groups were treated with $2.5 \mathrm{mg} \mathrm{L}^{-1}, 5.0 \mathrm{mg} \mathrm{L}^{-1}$ and $7.5 \mathrm{mg} \mathrm{L}^{-1}$ doses of methiocarb for $72 \mathrm{~h}$. (Tütüncü et al., 2019).

In another research, cyto-genotoxic effects of pinoxaden on the Allium cepa roots were investigated. Mitotic index (MI), mitotic phases, chromosomal aberrations (Aydın and Liman, 2020)

The study and study of lettuce-cultivated agricultural areas in the Mediterranean region found more than necessary pesticides were used in the fight against leaf aphids than necessary, and in the research conducted for the solution, Nasonovia ribisnigri, Rhopalosiphum nymhaeae, Aulacorthum solani were battled with 7 different leaf aphids, particularly. Spirotetramat and Thiomethoxam active ingredients used in the control ensured that the populations of harmful organisms were kept below the economic damage in the sprayings made before the core of the lettuce was formed (Sangün, 2010).

Plant protection is one of the main problems in citrus cultivation. Many chemical are used to deal with this problem In studies conducted in this area, it has been determined that Spirotetramat is harmless against $S$. gilvifrons adults, which are less harmful to S. pygmaeus, C. Montrouzieri larvae, A. melinus, C. montrouzieri adults (Şimşek 2011).

\section{Materials and Methods}

\subsection{Plant Material}

The certified Allium cepa L. bulbs were purchased from Ceylan Agricultural Company (Turkey).

\subsection{Rooting of Onion Bulbs}

A. cepa bulbs weighing approximately $4-5 \mathrm{~g}$ were rooted on the glass tubes containing distilled water for 48 hours in a dark environment at room temperature, with the root tips were kept in contact with water (Figure 1).

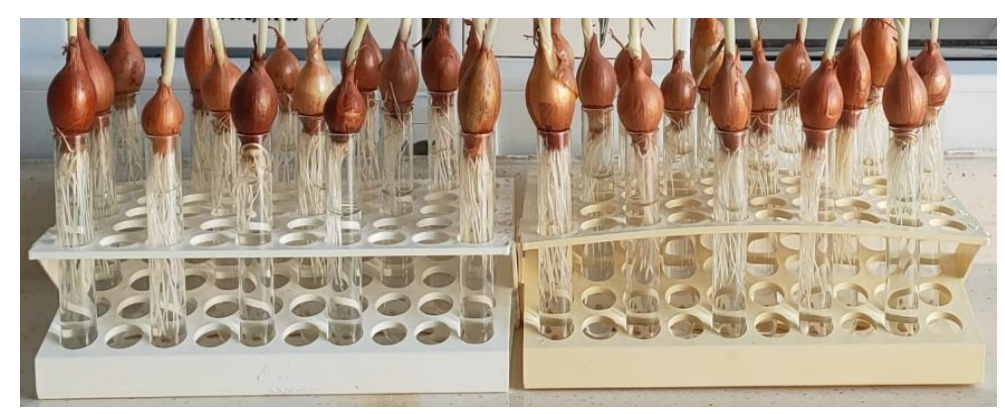

Figure 1- Rooted onion bulbs after 48 hours

26 | P a g e

www.iiste.org 


\subsection{Application of Spirotetramat to Allium cepa Bulbs}

Spirotetramat insecticide has been prepeared in three different doses as recommended dose $1 \mathrm{~mL} / \mathrm{L}$, two fold of recommended dose $2 \mathrm{~mL} / \mathrm{L}$ and four fold of recommended dose $4 \mathrm{~mL} / \mathrm{L}$. This doses has been given to rooted bulbs $(2-3 \mathrm{~cm})$ by adding to the irrigation water. Control group irrigated with distilled water. 24 and 48 hours after spirotetramat applications all of the root tips have been harvested early morning and washed with distilled water three times. Then root tips were taken into the farmer fixative ( 3 parts ethanol: 1 part glacial acetic acid) and then placed in the refrigerator in dark glass bottles at $+4{ }^{\circ} \mathrm{C}$ until microscopy. All of the experimental series has been realized three times.

\subsection{Mitotic Observations and Mitotic Index Calculation}

Allium root tips has been hydrolyzed with $1 \mathrm{~N} \mathrm{HCl}$ and were kept at $60^{\circ} \mathrm{C}$ for 11 minutes. Then, hydrolized root tips were stained by acetocarmine. Root tips kept in acetocarmine in falcon tubes for 48 hours in the refrigerator. Then, approximately $2-3 \mathrm{~mm}$ of root tips were cut from the darker colored ends of the root tips, acetocarmine was dropped on it again and a coverglass was covered. Microscopic observations of mitosis has been realized with Olympus CX-31 research microscope. For all treatment groups and control group 1000 cells have been counted to determine about mitotic index and chromosomal abnormalities.

By cytological observation of mitotic stages in meristematic cells, mitotic activity can be calculated. Mitotic activity is the ratio of dividing cells to non-dividing meristematic cells. It is generally used in chromosome count studies and toxicological studies. Thus, if there is application with a chemical substance, it gives information about how the substance has an effect on the splitting rate. The mitotic index is calculated in\% by the following formula

$$
M I=\left(\frac{\text { Number of Dividing Cells }}{\text { Total Number of Observed Cells }}\right) \times 100
$$

\subsection{Chromosomal Abnormality Frequecy Calculation}

The genotoxic effects of spirotetramat on A. cepa roots have been determined on the basis of chromosomal abnormality frequency (CAF). The chromosomal abnormalities were observed in each concentration of spirotetramat and control were evaluated in prophase, metaphase, anaphase and telophase by counting separately. Genotoxicity was evaluated based the CAF which was calculated by the formula $\mathrm{CAF}=[$ total number of cells with chromosomal abnormalities $(\mathrm{CA}) /$ total number of divided cells) $\mathrm{x} 100]$ at each concentration and compared with the control.

\section{Results and Discussion}

In our research, spirotetramat has been applied to the rooted bulbs by irrigation waters in three different doses $(1 \mathrm{ml} / \mathrm{L}, 2 \mathrm{ml} / \mathrm{L}$ and $4 \mathrm{ml} / \mathrm{L})$ for 24 and 48 hours exposure times. Genotoxic effects of spirotetramat has been determined by mitotic index and chromosomal abnormality frequency. Research results showed that spirotetramat induced significant increases of chromosomal aberrations such as metaphase table shift, anaphase pole shift, telophase pole shift, chromosomal bridge. In addition, mitotic index decreased significantly with increasing of concentrations and the exposure time when compared with control groups.

\subsection{Mitotic Index and Chromosomal Abnormalities Frequency Results \\ 3.1.1. Mitotic Index Results}

The cytotoxic effect of spirotetramat was investigated in A. cepa root tip cells in this research. The mitotic index have been decreased in root tip cells of $A$. cepa after 24 and 48 hours exposure time to 1 $\mathrm{mL} / \mathrm{L}, 2 \mathrm{~mL} / \mathrm{L}$ and $4 \mathrm{~mL} / \mathrm{L}$ spirotetramat when compared with control.

As a result of our research, it was understood that the mitotic index decreased in application groups when we compare with the control group. Applications of three different doses of spirotetramat with different exposure times affected mitosis and mitotic index (MI) negatively.

It was observed that the mitotic index decreased with increasing doses of spirotetramat doses. The decrease in mitotic index shows that insecticide used excessively instead of the recommended dose caused decreases in the mitotic index. We showed that this decreasing in mitotic index also depend to the exposure times. According to mitotic index results, when we compare with control group mitotic index decreased as $\% 56$ and $\% 65$ in $4 \mathrm{~mL} / 1$ spirotetramat applications after 24 and 48 hours respectively. Our research results are shown in tables (Table 1, Table 2, and Figure 2).

27 I P a g e

www.iiste.org 
International Journal of Scientific and Technological Research

Table 1. Mitotic index results in $A$. cepa root tip cells 24 hours after applications.

\begin{tabular}{|c|c|c|c|c|c|c|c|}
\hline $\begin{array}{c}\text { Concentrations } \\
(\mathbf{m L} / \mathbf{L})\end{array}$ & Prophase & Metaphase & Anaphase & Telophase & Divided Cells & $\begin{array}{c}\text { Total } \\
\text { Observed } \\
\text { Cells }\end{array}$ & $\begin{array}{c}\text { Mitotic } \\
\text { Index }\end{array}$ \\
\hline Control & 44 & 25 & 29 & 25 & 123 & 1249 & $9,85 \pm 0,95$ \\
\hline 1 & 35 & 19 & 22 & 18 & 94 & 1151 & $8,16 \pm 0,58$ \\
\hline 2 & 23 & 13 & 16 & 12 & 64 & 1023 & $6,25 \pm 0,89$ \\
\hline 4 & 16 & 10 & 12 & 8 & 46 & 1040 & $4,42 \pm 0,72$ \\
\hline
\end{tabular}

Table 2. Mitotic index results in $A$. cepa root tip cells 48 hours after applications.

\begin{tabular}{|c|c|c|c|c|c|c|c|}
\hline $\begin{array}{c}\text { Concentrations } \\
(\mathbf{m L} / \mathbf{L})\end{array}$ & Prophase & Metaphase & Anaphase & Telophase & Divided Cells & $\begin{array}{c}\text { Total } \\
\text { Observed } \\
\text { Cells }\end{array}$ & $\begin{array}{c}\text { Mitotic } \\
\text { Index }\end{array}$ \\
\hline Control & 42 & 22 & 25 & 21 & 110 & 1125 & $9,77 \pm 0,88$ \\
\hline 1 & 30 & 15 & 18 & 14 & 77 & 1023 & $7,52 \pm 0,65$ \\
\hline 2 & 22 & 9 & 12 & 8 & 51 & 1010 & $5,04 \pm 0,35$ \\
\hline 4 & 12 & 9 & 8 & 6 & 35 & 1020 & $3,43 \pm 0,64$ \\
\hline
\end{tabular}

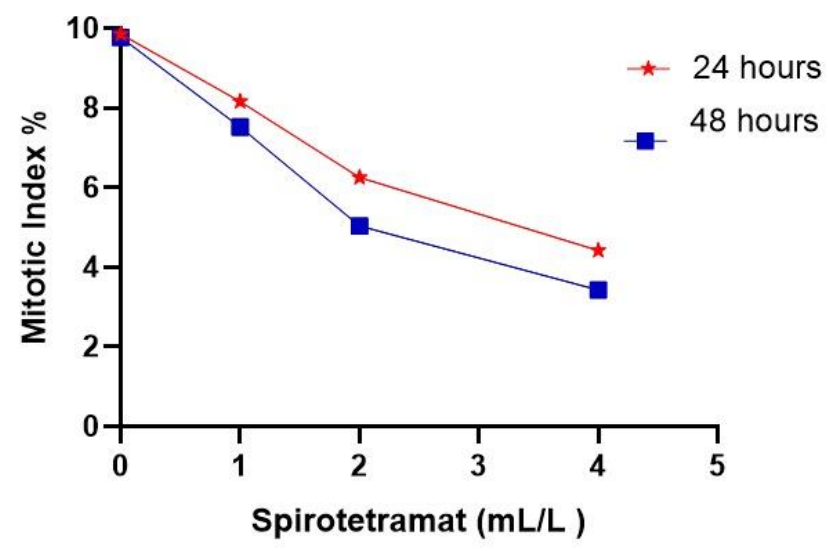

Figure 2- Comparing exposure times and doses in mitotic index

(Red: 24 hours after, Blue: 48 hours after application)

\subsubsection{Chromosomal Abnormalities Frequency Results}

As a result of our research, it was understood that the chromosomal aberrations increased in all application groups when we compare with the control group. The genotoxic effects of spirotetramat on $A$. cepa roots have been determined on the basis of chromosomal aberrations. The aberrations were observed in each concentration of spirotetramat and control were evaluated in prophase, metaphase, anaphase and telophase by counting separately. Research results has been showed that spirotetramat induced significant increases of chromosomal aberrations such as metaphase table shift, anaphase pole shift, telophase pole shift and chromosomal bridge. (Figure 3, Figure 4, Table 3, and Table 4.). 


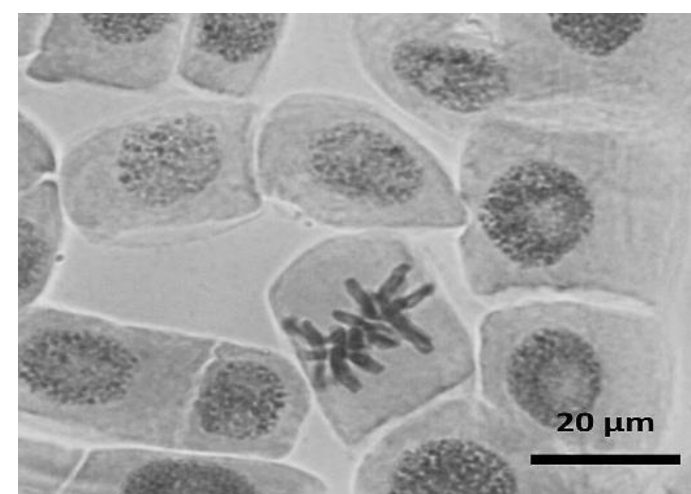

(A)

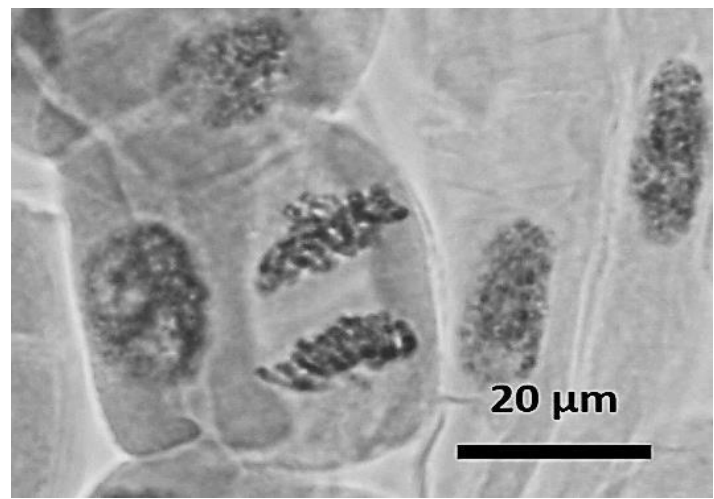

(C)

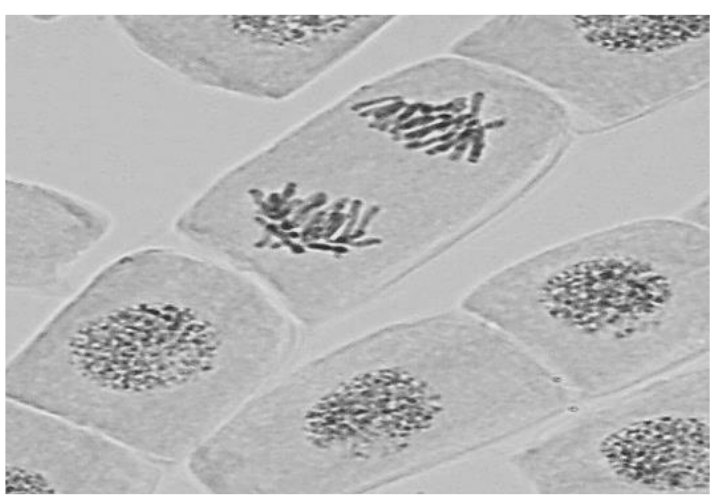

(B)

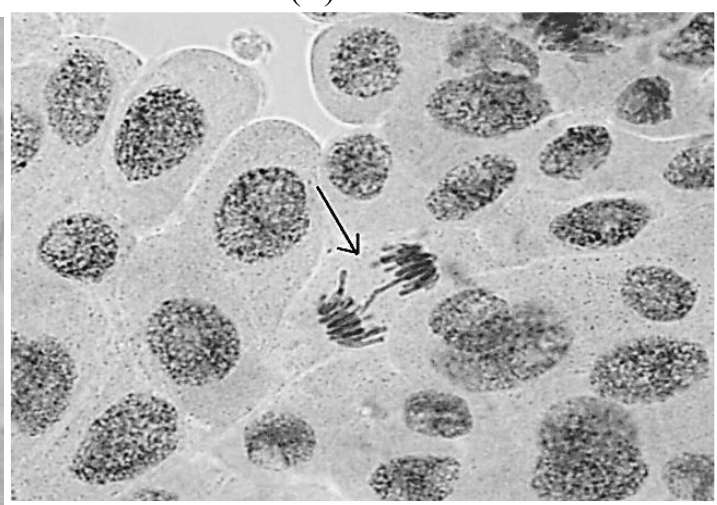

(D)

Figure 3- The genotoxic effects of spirotetramat on $A$. cepa root tip mitosis. (a) Metaphase table shift (b) Anaphase pole shift (c) Telophase pole shift (d) Chromosome Bridge

Table 3. Comparing different doses applications on chromosomal abnormality after 24 hours

\begin{tabular}{|c|c|c|c|c|c|c|c|}
\hline $\begin{array}{c}\text { Concentrations } \\
\text { (mL/L) }\end{array}$ & $\begin{array}{c}\text { Metaphase } \\
\text { table shift }\end{array}$ & $\begin{array}{c}\text { Anaphase } \\
\text { pole shift }\end{array}$ & $\begin{array}{c}\text { Telophase } \\
\text { pole shift }\end{array}$ & $\begin{array}{c}\text { Chromosome } \\
\text { Bridge }\end{array}$ & $\begin{array}{c}\text { Total } \\
\text { Abnormalities }\end{array}$ & $\begin{array}{c}\text { Divided } \\
\text { Cells }\end{array}$ & $\begin{array}{c}\text { Abnormality } \\
\text { Frequency }\end{array}$ \\
\hline Control & 3 & 1 & 2 & 1 & 7 & 123 & $5,69 \pm 0,78$ \\
\hline 1 & 3 & 3 & 1 & 1 & 8 & 94 & $8,51 \pm 0,54$ \\
\hline 2 & 4 & 2 & 3 & 2 & 11 & 64 & $17,18 \pm 0,78$ \\
\hline 4 & 5 & 6 & 5 & 4 & 20 & 46 & $43,47 \pm 0,48$ \\
\hline
\end{tabular}

Table 4. Comparing different doses applications on chromosomal abnormality after 48 hours

\begin{tabular}{|c|c|c|c|c|c|c|c|}
\hline $\begin{array}{c}\text { Concentrations } \\
(\mathbf{m L} / \mathbf{L})\end{array}$ & $\begin{array}{c}\text { Metaphase } \\
\text { table shift }\end{array}$ & $\begin{array}{c}\text { Anaphase } \\
\text { pole shift }\end{array}$ & $\begin{array}{c}\text { Telophase } \\
\text { pole shift }\end{array}$ & $\begin{array}{c}\text { Chromosome } \\
\text { Bridge }\end{array}$ & $\begin{array}{c}\text { Total } \\
\text { Abnormalities }\end{array}$ & $\begin{array}{c}\text { Divided } \\
\text { Cells }\end{array}$ & $\begin{array}{c}\text { Abnormality } \\
\text { Frequency }\end{array}$ \\
\hline Control & 3 & 2 & 2 & 1 & 8 & 110 & $7,27 \pm 0,87$ \\
\hline 1 & 5 & 6 & 1 & 2 & 14 & 77 & $18,18 \pm 0,74$ \\
\hline 2 & 6 & 4 & 1 & 2 & 13 & 51 & $25,49 \pm 0,36$ \\
\hline 4 & 7 & 4 & 5 & 2 & 18 & 35 & $51,42 \pm 0,46$ \\
\hline
\end{tabular}




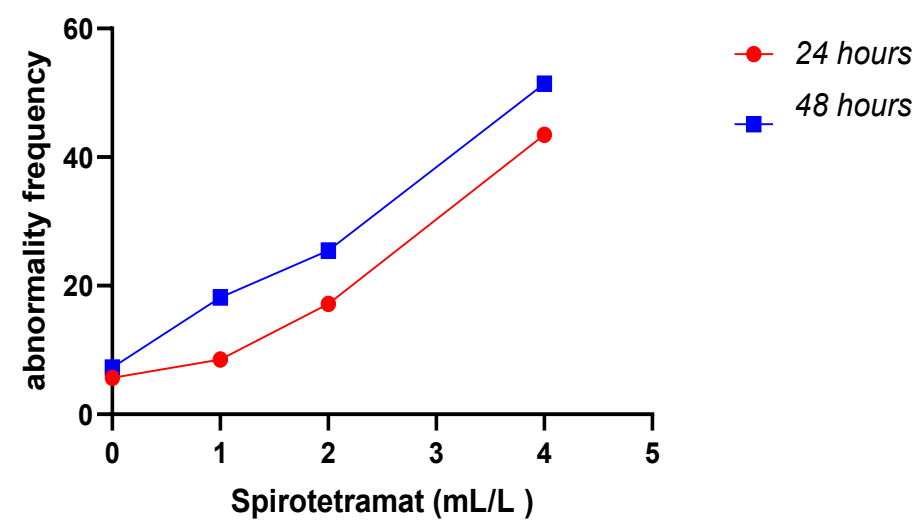

Figure 4- Comparing 24 and 48 hours spirotetramat applications on chromosomal abnormality frequency.

Applications of three different doses of spirotetramat with different exposure times affected chromosomal aberration frequency (CAF) in $A$. cepa at different levels. It was observed that the CAF increased with increasing doses of spirotetramat. The increase in CAF shows that insecticide used excessively instead of the recommended dose caused increases in the CAF. We showed that this increasing in $\mathrm{CAF}$ also depend to the exposure times. According to CAF results, when we compare with control group CAF increased approximately seven folds in $4 \mathrm{~mL} / 1$ spirotetramat applications after 24 and 48 hours. After the spirotetramat applications different kind of chromosomal abnormalities have been observed.

\subsection{Discussion}

Our research results have been showed that spirotetramat decreased the mitotic cell division frequency and induced chromosomal aberrations with increasing concentration and exposure time. Our results showing parallelity with other researchers results about $A$. cepa root tips with different pesticides like benomyl (Dane and Dalgiç, 2005), raxil (Fisun, and Rasgele, 2009), thiabendazole (Andrioli and Mudry, 2011), fenbuconazole (Türkoğlu, 2012), flusilazole (Ozakca and Silah, 2013). In parallel to our results, it was reported that these kind of pesticides can create a lot of different chromosomal abnormalities and decrease the mitotic index, depending on the concentrations and exposure times.

In another research, genotoxic and cytotoxic effects of three dodine fungicide concenrations as 0.04 $\mathrm{mL} / \mathrm{L}, 0.08 \mathrm{~mL} / \mathrm{L}$ and $0.16 \mathrm{~mL} / \mathrm{L}$ on $A$. серa has been revealed. Research results showed that dodine induced significant increases of chromosomal aberrations and mitotic index decreased significantly with increasing of concentration and the exposure time (Çördük et al., 2015). Some researchers suggest that the reduction of mitotic activity may be due to inhibition of DNA synthesis (Butt and Vahidy, 1994).

In another research, genotoxic effect of fipronil insecticide have been shown in $A$. cepa root tips by mitotic index and chromosomal abnormalities. As a result of this research, percentages of mitotic stages have been significantly affected and fipronil markedly enhanced the abnormality cell percentage in almost all of the concentrations and treatment times compared to the control. Among chromosomal abnormalities disturbed prophase, sticky, chromatid bridges and laggards have been observed. The genotoxic potential of fipronil insecticide with different assessments were evaluated by using the $A$. cepa (Karaismailoglu, 2017).

As a result of another research toxic effects of methiocarb insecticide were investigated in Allium cepa. Methiocarb administration caused an increase in the number of $\mathrm{MN}$ and chromosomal damage, and a decrease in MI on the cells of root tips. As a result, methiocarb caused toxic effects, and the Allium test material was found to be a useful bioindicator for monitoring these effects. (Tütüncü et al., 2019).

In another research, three different concentrations of pinoxaden $1.25 \mathrm{mg} / \mathrm{L}, 2.5 \mathrm{mg} / \mathrm{L}$ and $5 \mathrm{mg} / \mathrm{L}$ and methyl methane sulphonate (MMS, $10 \mathrm{mg} / \mathrm{L}$ ) for positive control and distilled water for negative control were exposed to Allium bulbs for 24, 48, 72 and 96 hours. Pinoxaden showed cytotoxic effects by decreasing the root growth and MI. Pinoxaden induced CAs including anaphase bridges, chromosome laggards, stickiness and polyploidy (Aydın and Liman, 2020)

30 | P a g e

www.iiste.org 
In our research genotoxic effects of spirotetramat on $A$. cepa root tips have been determined on the basis of chromosomal aberrations and mitotic index. The aberrations were observed in each concentration of spirotetramat application. All of the observed chromosomal abnormalities in each phase were calculated as chromosomal aberration frequency (CAF). As a result, since spirotetramat increased the CAF and decrease in MI in A. cepa, over-application of spirotetramat can be accepted as a genotoxic agent for some plant species.

\section{Conclusion}

Our results have showed that one more time $A$. cepa is a successful model plant for determining the cytotoxicity and genotoxicity of spirotetramat and other pesticides. Our data have been showed that spirotetramat has potentially genotoxic and cytotoxic effects on $A$. cepa plant. For this reason, it is very important to control that the using of spirotetramat should be under control because it may has toxic effects on farmers and humans which produce and consume this plants. Hence spirotetramat should be use under control in agricultural fields due to its possible toxic effects.

\section{References}

Andrioli N.B and Mudry M.D. (2011) Cytological and cytogenetic effects induced by thiabendazole on Allium cepa root meristems. J Basic Appl Genet 22(2), 17-23.

Aydın G., Liman R. (2020). Cyto-genotoxic effects of Pinoxaden on Allium cepa L. roots. Journal of applied genetics, 61, 349-357.

Butt S.K., and Vahidy A.A. (1994). Cytotoxic Effects of Herbicide Ronstar on Meristematic Cells of Allium cepa L. Pak. J. Bot, 26(1), 69-74.

Çördük N., Akıncı N., Yücel G., Kaya N., Akı C. (2015). Evaluation of Genotoxicity and Cytotoxicity of Dodine (1-dodecylguanidium acetate) by Allium Test. Fresen Environ Bull, 24, $4527-4531$

Dağ S.S., Aykaç, V.T., Gündüz, A., Kantarc1, M., Şişman, N. “Türkiye'de Tarım İlaçları Endüstrisi ve Geleceği”, ERIŞSiM: http://www.zmo.org.tr/etkinlikler/5tk02/40.pdf 06.05.2007

Dane F. and Dalgiç Ö. (2005). The effects of fungicide benomyl (benlate) on growth and mitosis in onion (Allium cepa L.) root apical meristem. Acta Biol Hung 56 (1-2), 119-128.

Durmuşoğlu E., Tiryaki O., Canhilal R. 2010. Türkiye'de Pestisit Kullanımı, Kalıntı ve Dayanıklılık Sorunları. VII. Türkiye Ziraat Mühendisliği Teknik Kongresi, Ankara.

El-Shahaby O. A., Abdel Migid H.M., Soliman M. I., Mashaly, I.A. (2003). Genotoxicity screeningof industrial wastewater using the Allium cepa chromosome aberration assay, Pak. J. Biol. Sci., 6, 23-28.

Fisun K., Rasgele P.G. (2009). Genotoxic Effects of Raxil on Root Tips and Anthers of Allium cepa L. Caryologia 62(1), 1-9.

Guest M., Kriek N., Flemming A.J. (2020). Studies of an insecticidal inhibitor of acetyl-CoA carboxylase in the nematode C. elegans. Pesticide Biochemistry and Physiology, 169, 104604.

Karaismailoğğu M.C. (2017). Assessments on the potential genotoxic effects of fipronil insecticide on Allium cepa somatic cells. Caryologia, 70(4), 378-384.

K1lıc, S., (2013). "Çevre Sorunları ve Yoksulluk", Uluslararası Alanya İşletme Fakültesi Dergisi, $5: 1(9-20)$. 
Kuraś M., Nowakowska J., Śliwińska E., Pilarski R., Ilasz R., Tykarska T., Gulewicz K. (2006). Changes in chromosome structure, mitotic activity and nuclear DNA content from cells of Allium Test induced by bark water extract of Uncaria tomentosa DC, Journal of Ethnopharmacology,107, 211-221.

Ozakça D.U., Silah H. (2013). Genotoxicity effects of Flusilazole on the somatic cells of Allium сера. Pesticide biochemistry and physiology, 107(1), 38-43.

Rank, J. (2003). The method of Allium anaphase-telophase chromosome aberration assay. Ekologija, 1(1), 38-42.

Sangün, O. (2010). Doğu Akdeniz bölgesi marul ekim alanlarında zararlı olan Aphididae (Hemiptera) türleri ve bunların mücadelesine yönelik araştırmalar. Çukurova Üniversitesi / Fen Bilimleri Enstitüsü, Yüksek Lisans Tezi.

Şimşek VM, Uygun N. (2013). Bazı tarımsal savaş ilaçlarının turunçgil bahçelerindeki önemli parazitoit ve predatörlere etkilerinin laboratuvar koşullarında araştırılması, Türk. biyo. müc. derg., 4(2):141-154.

Teixeira R.D.O., Camparoto M.L., Mantovani M.S., Vicentini V.E.P. (2003). Assessment of two medicinal plants, Psidium guajava L. and Achillea millefolium L., in in vitro and in vivo assays. Genetics and Molecular Biology, 26, 551-555.

Türkoğlu Ş. (2012). Determination of genotoxic effects of chlorfenvinphos and fenbuconazole in Allium cepa root cells by mitotic activity, chromosome aberration, DNA content, and comet assay. Pestic Biochem Phys 103(3), 224-230.

Tütüncü E., Yalçin E., Acar A., Yapar K., Çavuşoğlu K. (2019). Investigation of the Toxic Effects of a Carbamate Insecticide Methiocarb in Allium cepa L. Cytologia, 84(2), 113-117.

Vicentini V. E. P., Camparoto M.L., Teixeira R. O., Mantovani M.S. (2001). Averrhoa carambola L., Syzygium cumini (L.) Skeels and Cissus sicyoides L.: Medicinal Herbal Tea Effects on Vegetal and Animal Test systems. Acta Scientiarum, 23(2), 593-598.

www.fao.org/fileadmin/templates/agphome/documents/Pests_Pesticides/JMPR/Report08/Spirotetra mat.pdf (Date of access ; 20.06.2021).

Yadav I.C., Devi, N.L. (2017). Pesticides Classification and Its Impact on Human and Environment. Environmental Science and Engineering, 6, 140-158. 